RESEARCH ARTICLE

\title{
Morphological and molecular divergence of subspecies of Indian Bush Rats, Golunda ellioti Gray, 1837 (Rodentia: Muridae) from Sri Lanka
}

\author{
P.P.C. Hemamali and S.H. Boyagoda*
}

Department of Zoology, Faculty of Science, University of Peradeniya, Peradeniya, Sri Lanka

Received: 25/02/2019 ; Accepted: 27/07/2019

\begin{abstract}
Genus Golunda is comprised of a single species of small bush rat endemic to southern Asia. In Sri Lanka, two subspecies are recognized, Golunda ellioti ellioti (Indian bush rat) and G. e. nuwara (Ceylon bush rat). These two subspecies can be differentiated by their tail length (longer in G. e. ellioti vs shorter in G. e. nuwara) fur type (short, harsh, spinous in G. e. ellioti vs long, soft and moderately fine in G. e. nuwara), colour of ventral pelage (light grey in G. e. ellioti vs bluish grey in G. e. nuwara) and microscopic hair anatomy (broader and shorter Guard Hair 1 with triangular and square shaped cross sections at the tip of the shield in G. e. ellioti vs narrower and longer Guard Hair 1 with circular to oval shaped cross sections in G. e. nuwara). In the present study, the divergence between the two subspecies was further evaluated using morphology (external and cranial) and molecular data (cytochrome- $b, 16 \mathrm{~S}$ and Rag 1 genes). We found that the brain case was comparatively rounded in G. e. ellioti and the interparietal bone was elongated in G. e. nuwara. Genetic distance between the two subspecies remain at subspecies level; $1.2 \%$ for cytochrome- $b$.
\end{abstract}

Keywords: coffee rat, taxonomy, mitochondrial genes, Peradeniya, Horton Plains.

\section{INTRODUCTION}

Golunda (Indian bush rat or Coffee rat), at present is a monotypic genus. During 1980's multiple species of Golunda were described from India and Sri Lanka, but they were all referred to a single species Golunda ellioti by Thomas (1923). Later, at least 10 subspecies were described, which are distributed in Southeast Iran, Pakistan, Nepal, India and Sri Lanka (Ellerman 1941). Of these, six are from India (G. e. limitaris, G. e. pupera, G. e. watsoni, G. e. gujerati, G. e. bombax, G. e. caraginis), one from Nepal (G. e. myiothrix), one from Bhutan (G. e. coenosa), one from Sri Lanka (G. e. nuwara) and one from India and Sri Lanka (G. e. ellioti). Ellerman, in 1947 and 1963, gradually reduced the number of subspecies synonymizing all but G. e. nuwara with the nominate subspecies. Agrawal and Chakraborty (1982) after studying in detail of the intraspecific variations of the Indian Bush rat from different geographical areas concluded that only G. e. gujerati, G. e. nuwara and G. e. ellioti are valid subspecies.

In Sri Lanka, Kelaart (1850) recognized two species of Golunda (Kelaart, 1852), which were earlier described under the genus Mus: Mus newera "The Newera Eliya Soil Rat" and M. ellioti "Coffee rat". Later, both species were described as subspecies of Golunda ellioti [G. ellioti newera: later spelt as nuwara (Phillips 1980) and G.e. ellioti] by Phillips (1928). As stated by Phillips (1928), Kelaart was correct in describing two forms of Golunda from the island, as they can be readily distinguished from each other. Golunda newera can be distinguished from $G$. ellioti by their general colour of speckled yellowish olive brown and black, and long, untidy, soft fur. Golunda ellioti, on the other hand, has a general colour of sandy or tawny brown and black, with short, smooth and harsh fur, with the dorsal hairs very spinous. Even though these pelage characteristics are commonly associated with elevation gradient within species, Kelaart (1852) and Phillips (1928) regarded them as distinguishing characteristics. Though Phillips (1928) mentioned that the external and skull measurements were very much alike in the two species, Kelaart (1852) differentiated the two by body size and tail length also. Golunda e. ellioti has a longer tail proportionately to head and body size compared to G. e. nuwara (Kelaart,1852; Phillips 1980; Agrawal and Chakraborty, 1982).

Golunda e. ellioti (Indian bush rat) is found throughout Southwestern lowland wet zone and mid country hills of Central and Uva provinces to approximately $900 \mathrm{~m}$ altitudes (Phillips, 1980). This subspecies has previously reported from Kalugala, Kegalle, Kantalai, Polonnaruwa, Baddegama, Ettakando, Palatupana, Hambantota, Attidiya and Dehiwala in Sri Lanka (Molur et al. 2005). Golunda ellioti nuwara (The Ceylon Bush-rat or Coffee-Rat), which is endemic to Sri Lanka, is confined to the jungles and swamps in the higher areas of the central mountains above altitudes of approximately $1200 \mathrm{~m}$ (Phillips, 1980). At medium altitudes the two subspecies meet and grade into one another (Phillips, 1980) but no studies have been conducted to show whether they interbreed or not.

A later study showed that the two subspecies could be differentiated by their microscopic hair anatomy. Cross sections at the tip of shield of Guard Hair 1 (GH 1) is triangular and square shaped in G. e. ellioti, while that of G. e. nuwara is circular to oval shaped (Figure 1). GH 1 


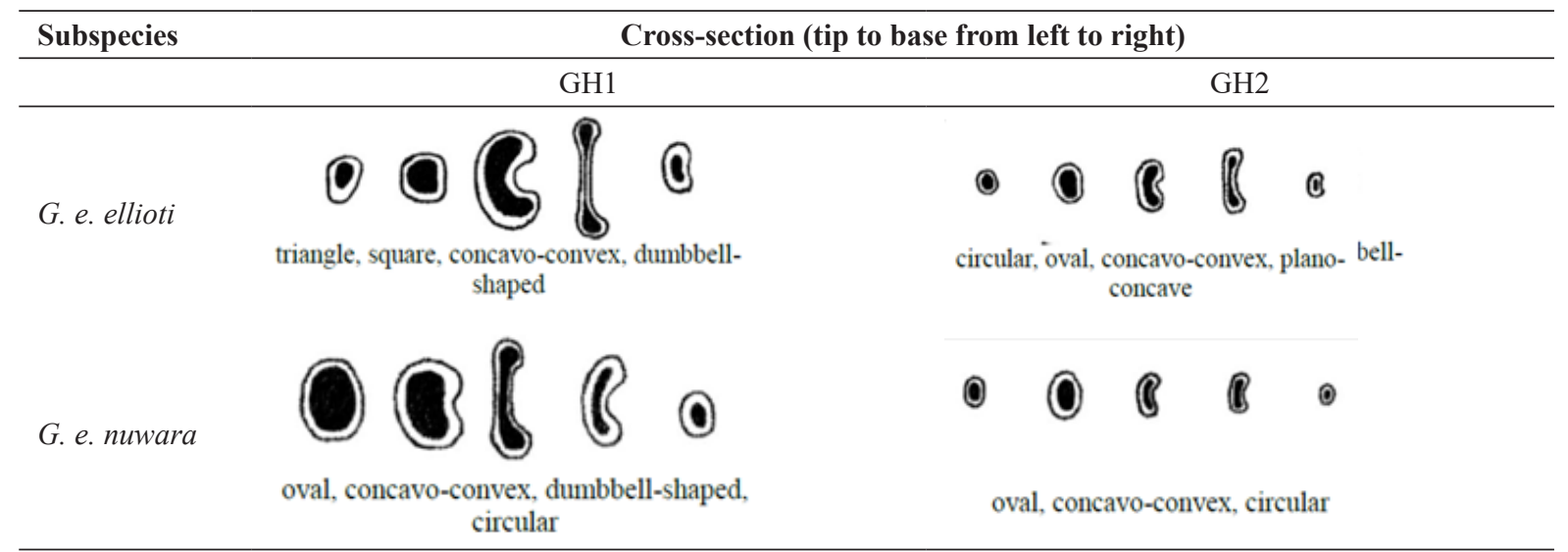

Figure 1: Cross sections at the tip of shield of Guard Hair $1(\mathrm{GH} 1)$ and Guard Hair $2(\mathrm{GH} 2)$ of G. e. ellioti and that of G. e. nuwara (Niroshani and Meegaskumbura, 2015)

Table 1: Width and length of Guard Hair 1 (GH1) and Guard Hair 2 (GH2) of G. e. ellioti and that of G. e. nuwara (Niroshani and Meegaskumbura, 2015)

\begin{tabular}{lllll}
\hline Subspecies & \multicolumn{2}{c}{ GH1 } & GH2 \\
& Length $(\mathbf{m m})$ & Maximum width $(\boldsymbol{\mu m})$ & Length $(\mathbf{m m})$ & Maximum width $(\boldsymbol{\mu m})$ \\
\hline G. e. ellioti & $9.0-12.9(11.1 \pm 0.9)$ & $80-200(146 \pm 43)$ & $7.8-13.2(11.0 \pm 1.6)$ & $30-50(37 \pm 8)$ \\
G. e. nuwara & $14.0-21.1(17.3 \pm 2.5)$ & $60-90(82 \pm 9)$ & $12.9-17.1(16.0 \pm 1.4)$ & $30-50(42 \pm 7)$ \\
\hline
\end{tabular}

of $G$. e. ellioti are broader and shorter compared to $G$. e. nuwara, however, Guard Hair 2 (GH2) dimensions overlap between the two subspecies (Table 1) (Niroshani and Meegaskumbura, 2015).

The subspecies are conceived of as genetically distinct, geographically separate populations belonging to the same species and therefore interbreeding freely at the zones of contact (Wilson and William, 1953). Taxonomic rank of subspecies has been a controversy for decades. Even though some are unwilling to accept subspecies as useful, others argue that they represent populations diverging towards species level diversification, hence an important taxonomic unit (Phillimore and Owens, 2006).

Golunda ellioti has been tested phylogenetically, where it falls with an African murine rodent Hybomys univittatus (Ducroz et al., 2001). However, none of the subspecies have been analyzed molecularly. Hence, the objective of the present study was to further compare the two subspecies present in Sri Lanka using morphometrics, skull characters, genetic divergence and test their phylogenetic positions.

\section{MATERIALS AND METHODS}

Two specimens of G. e. nuwara from Horton plains and three specimens of $G$. e. ellioti from a grassland near a small coffee plantation in Peradeniya were collected. One hundred wire mesh cage traps baited with pieces of roasted coconut were used to collect specimens. A muscle sample was taken from each specimen and preserved in $90 \%$ ethanol for DNA analysis. Skulls were cleaned and skins were prepared. Two skulls of G. e. nuwara from the
National Museum, Sri Lanka were also included in the study. Their external measurements were collected from logbooks. Five external measurements [length of head and body (HBL), length of head (HL), length of tail (TL), length of hindfoot (HFL) and ear height (EH)], twenty-six skull measurements (Figure 2), external morphology and skull characters were used to compare subspecies. External and cranial measurements were not statistically analyzed because some of the specimens were sub-adults. All adults collected were females.

DNA was extracted from ethanol-preserved tissues using Promega tissue extraction kits following manufacturer's protocol. Two mitochondrial gene fragments (16S rRNA and cytochrome- $b$ ) and one nuclear fragment (Rag 1) were sequenced. DNA was amplified by PCR using $25 \mu \mathrm{l}$ reactions containing $2.0 \mu \mathrm{l}$ of template, $1.0 \mu \mathrm{l}$ of each primer $(10 \mu \mathrm{M})$, and $12.5 \mu \mathrm{l}$ GoTaq Green master mix, topped with nano water. Thermal cycling for the Cytochrome- $b$ fragment was as follows: 35 cycles of denaturation at $94^{\circ}$ $\mathrm{C}$ for $30 \mathrm{~s}$, annealing at $45^{\circ} \mathrm{C}$ for $30 \mathrm{~s}$, and extension at $72^{\circ}$ $\mathrm{C}$ for $1 \mathrm{~min}$, with a final extension of $72^{\circ} \mathrm{C}$ for $5 \mathrm{~min}$. The same conditions were used to amplify $16 \mathrm{~S}$, except that the annealing temperature of $48^{\circ} \mathrm{C}$. Thermal cycling for Rag 1 gene (819 bp) was as follows: 35 cycles of denaturation at $95^{\circ} \mathrm{C}$ for $45 \mathrm{~s}$, annealing at $55^{\circ} \mathrm{C}$ for $45 \mathrm{~s}$, and extension at $72^{\circ} \mathrm{C}$ for $1 \mathrm{~min}$, with a final extension of $72^{\circ} \mathrm{C}$ for $5 \mathrm{~min}$.

Cytochrome- $b$ and $16 \mathrm{~S}$ were amplified using the primers MVZ 05/ MVZ 14 and 16Sar/ 16Sbr, respectively. Primer sequences are as follows: MVZ 05 5' CGA AGC TTG ATA TGA AAA ACC ATC GTTG 3'; MVZ 14 5', 
GGT CTT CAT CTY HGG YTT ACA AGAC 3'; 16S ar 5' CGC CTG TTT ATC AAA AAC AT 3'; $16 \mathrm{~S}$ br 5' CCG GTC TGA ACT CAG ATC ACGT 3'. Sequence length of cytochrome- $b$ and $16 \mathrm{~S}$ were 1140 and 547 base pairs, respectively. Primers used for Rag 1 PCR were: AmpRAG1 F 5' AGC TGCAGY CAR TAC CAY AAR ATG TA 3'; Amp RAG1R1 5'AAC TCA GCT GCA TTK CCA ATR
TCACA 3'. Sequences were cleaned using ChromasPro 1.7.7 and phylogenies and uncorrected percentage genetic distance values for cytochrome- $b$ gene were generated using MEGA 6 software. Sequences were submitted to the GenBank. Details of the taxa included in the study are presented in Table 2 .
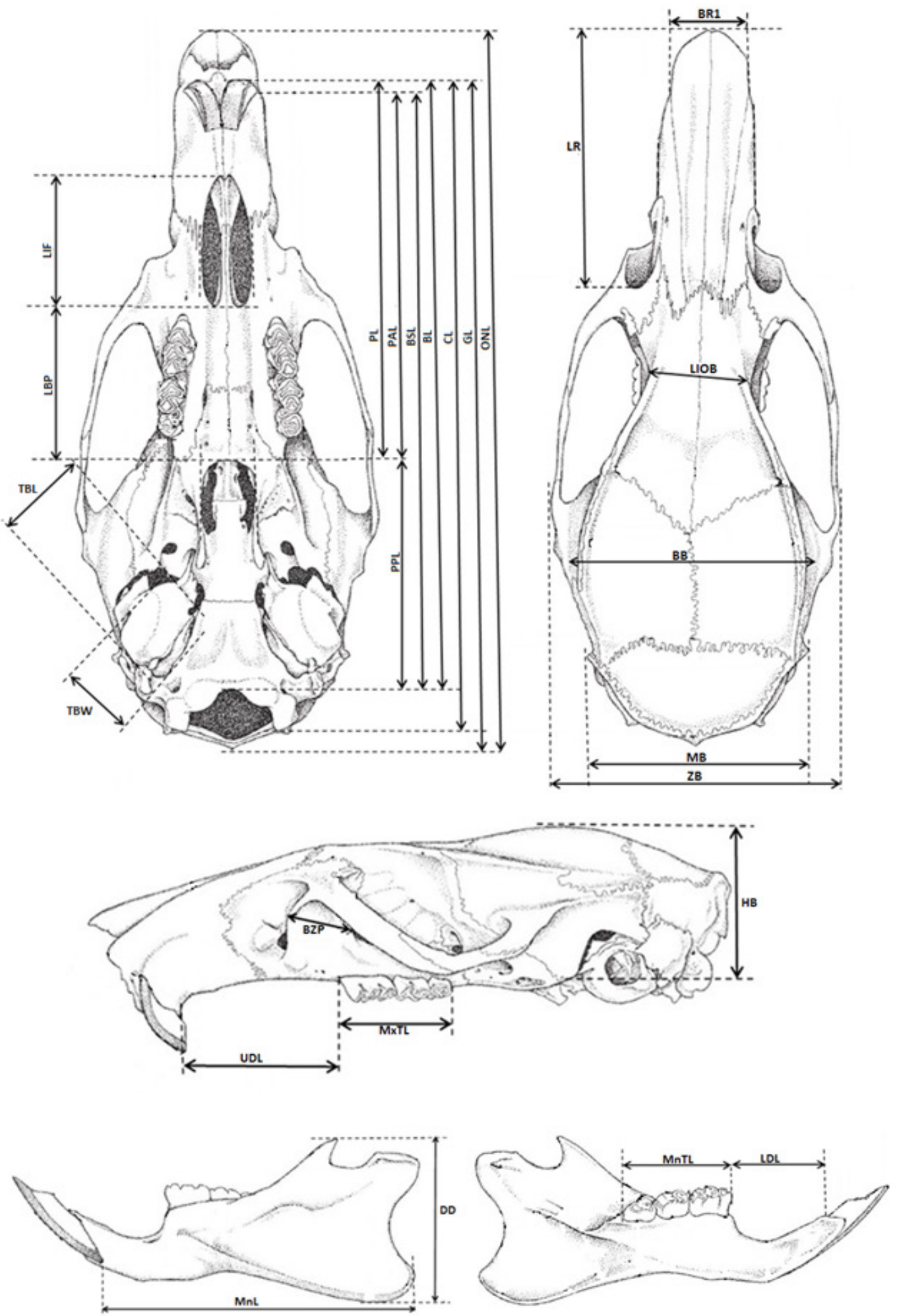

Figure 2: Dorsal, ventral and lateral views of cranium of a murine rodent (and mandible in the latter case), illustrating measurements taken in this study (refer Table 4 for abbreviations). (Figure modified from Musser et al., 2006; measurements from Buttler and Greenwood, 1979; Musser et al., 2006; Meegaskumbura et al., 2007) 
Table 2: Collection site, voucher numbers and GenBank accession numbers of gene sequences of taxa included in the study. Except Tatera indica from Pakistan and Golunda ellioti from India, all other specimens were collected from Sri Lanka.

\begin{tabular}{|c|c|c|c|}
\hline Species & $\begin{array}{l}\text { Collection site (Longitude, Latitude, } \\
\text { Elevation; reference if the sequence } \\
\text { was obtained from Genbank) }\end{array}$ & $\begin{array}{l}\text { Voucher } \\
\text { number }\end{array}$ & $\begin{array}{l}\text { GenBank accession number } \\
\text { of cytochrome-b/16S/Rag1 } \\
\text { sequences }\end{array}$ \\
\hline \multirow{3}{*}{ Golunda ellioti ellioti } & $\begin{array}{l}\text { Peradeniya }\left(07^{\circ} 25^{\prime} \mathrm{N}, 80^{\circ} 59^{\prime} \mathrm{E} \text {, elevation }\right. \\
488 \mathrm{~m})\end{array}$ & PDZ 7 & —/KY986860/ MN150143 \\
\hline & $\begin{array}{l}\text { Peradeniya }\left(07^{\circ} 25^{\prime} \mathrm{N}, 80^{\circ} 59^{\prime} \mathrm{E} \text {, elevation }\right. \\
488 \mathrm{~m})\end{array}$ & PDZ 11 & $\begin{array}{l}\text { KY986802/ KY986861/ } \\
\text { XX000000 }\end{array}$ \\
\hline & $\begin{array}{l}\text { Paymadu (National Museum, Colombo; } \\
\text { collection date 13.09.1935) }\end{array}$ & 750 & - \\
\hline Golunda ellioti & India (Michaux et al. 2007) & - & AM408338/ - \\
\hline \multirow{4}{*}{ Golunda ellioti nuwara } & $\begin{array}{l}\text { Horton Plains }\left(06^{0} 80^{\prime} \mathrm{N}, 80^{\circ} 83^{\prime} \mathrm{E},\right. \\
\text { elevation } 2150 \mathrm{~m})\end{array}$ & WHT M 141 & $\begin{array}{l}\text { KY986801/ KY986862/ } \\
\text { MN150145 }\end{array}$ \\
\hline & $\begin{array}{l}\text { Horton Plains }\left(06^{\circ} 80^{\prime} \mathrm{N}, 80^{\circ} 83^{\prime} \mathrm{E} \text {, }\right. \\
\text { elevation } 2150 \mathrm{~m})\end{array}$ & WHT M 032 & —/KY986863/ MN150144 \\
\hline & $\begin{array}{l}\text { West Haputhale, Ohiya (National } \\
\text { Museum, Colombo; collection date } \\
\text { 12.08.1931) }\end{array}$ & $75 \mathrm{P}$ & - \\
\hline & $\begin{array}{l}\text { West Haputhale, Ohiya (National } \\
\text { Museum, Colombo; collection date } \\
\text { 19.06.1931) }\end{array}$ & $75 \mathrm{M}$ & - \\
\hline Bandicota indica & $\begin{array}{l}\text { Galle }\left(06^{0} 03^{\prime} \mathrm{N}, 80^{\circ} 22^{\prime} \mathrm{E} \text {, elevation }\right. \\
7.2 \mathrm{~m})\end{array}$ & PDZ 43 & KY697990/KY673247 \\
\hline Rattus norvegicus & $\begin{array}{l}\text { Galle }\left(06^{0} 03^{\prime} \mathrm{N}, 80^{\circ} 22^{\prime} \mathrm{E} \text {, elevation }\right. \\
7.2 \mathrm{~m})\end{array}$ & PDZ 44 & KY697996/KY673255 \\
\hline Rattus rattus kandianus & $\begin{array}{l}\text { Udawalawe }\left(06^{0} 47^{\prime} \mathrm{N}, 80^{\circ} 90^{\prime} \mathrm{E} \text {, }\right. \\
\text { elevation } 112.2 \mathrm{~m})\end{array}$ & WHT 6926 & KY697997/KY673254 \\
\hline Mus cervicolor & $\begin{array}{l}\text { Agarapathana }\left(06^{0} 87^{\prime} \mathrm{N}, 80^{0} 72^{\prime} \mathrm{E},\right. \\
\text { elevation } 1378.0 \mathrm{~m})\end{array}$ & WHT 6873 & KY697998/KY673256 \\
\hline Mus musculus & $\begin{array}{l}\text { Agarapathana }\left(06^{0} 87^{\prime} \mathrm{N}, 80^{0} 72^{\prime} \mathrm{E} \text {, }\right. \\
\text { elevation } 1378.0 \mathrm{~m})\end{array}$ & WHT 6886 & KY697999/KY673257 \\
\hline \multirow{2}{*}{ Tatera indica } & Pakistan (Chevret and Dobigny 2005) & - & AJ430563/ - \\
\hline & $\begin{array}{l}\text { Yala }\left(06^{0} 43^{\prime} \mathrm{N}, 81^{0} 31^{\prime} \mathrm{E} \text {, elevation }\right. \\
29.4 \mathrm{~m})\end{array}$ & WHT 6893 & $-/$ KY 673258 \\
\hline
\end{tabular}

\section{RESULTS}

Considering external measurements, similar to descriptions given by Phillips (1980) G. e. nuwara (HBL: 140-148 mm) was larger than G. e. ellioti (HBL: 137.8-138.85 mm). But tail length was longer in G. e. ellioti (TL: 104.8-108.35 $\mathrm{mm}$ ) than that of G. e. nuwara (TL: 90-101 mm) (Table 3).

Golunda e. nuwara has larger skull parameters than $G$. e. ellioti. Especially the GL, CL, BL, BSL, PPL, PAL, PL, LBP, upper jaw dental measurements (MTL, UM1B) and lower jaw incisor length (LIL1) of G. e. nuwara were larger than those of G. e. ellioti (Table 3). Interparietal bone of $G$. e. ellioti is rounded in shape (Figure 3A1-c) but that of $G$. e. nuwara is elongated (Figure 3B1-d). Braincase of G. e. ellioti is comparatively rounded (Figure 3A1-e) than that of G. e. nuwara (Figure 3B1-f).
Considering lower jaw morphology, the base of the lower jaw posterior to the angular process was rather flat in G. e. ellioti (Figure 3A4-h) while that of G. e. nuwara is somewhat elongated and curved (Figure 3B4-g). Golunda e. ellioti also has a smaller diastema (Figure 3A5-i) than $\mathrm{G}$. e. nuwara (Figure 3B5-j) (Table 4:LDL). 
Table 3: External measurements (mm) of Golunda ellioti nuwara, and G. e. ellioti. (SA- Sub Adult)

\begin{tabular}{lllllll}
\hline & \multicolumn{3}{l}{ G. $\boldsymbol{e}$. nuwara } & \multicolumn{3}{l}{ G. e. ellioti } \\
\hline & $\mathbf{7 5 P}$ & $\mathbf{7 5 M}$ & WHT M 032 (SA) & PDZ 7 & PDZ 11 & 750 (SA) \\
\hline Head and Body Length (HBL) & 148 & 140 & 110.3 & 137.8 & 138.85 & 120 \\
\hline Tail Length (TL) & 101 & 90 & 99.8 & 104.8 & 108.35 & 104 \\
\hline TL/HBL*100 & 68.24 & 64.29 & 90.48 & 76.05 & 78.03 & 86.67 \\
\hline Ear Height (EH) & 16 & 20 & 17.7 & 17 & 17 & 16 \\
\hline Hind foot Length (HFL) & 28 & 27 & 26.9 & 27.2 & 27.8 & 26 \\
\hline
\end{tabular}

Table 4: Skull measurements (mm) of Golunda ellioti nuwara and G. e. ellioti.

\begin{tabular}{|c|c|c|c|c|c|c|}
\hline \multirow{2}{*}{ Abbreviation } & \multirow{2}{*}{ Measurement } & \multicolumn{3}{|c|}{ G. e. nuwara } & \multicolumn{2}{|c|}{ G. e. ellioti } \\
\hline & & $75 \mathrm{P}$ & $75 M$ & WHT M 141 & PDZ 7 & PDZ 11 \\
\hline ONL & Occipitonasal Length & 33.3 & 34.13 & 36.25 & 33.25 & 33.4 \\
\hline GL & Greatest Length of the skull & 32.89 & 33.49 & 34.3 & 31.85 & 31.5 \\
\hline CL & Condylobasal Length & 31.9 & 32.5 & 32.5 & 30.1 & 30.35 \\
\hline $\mathrm{BL}$ & Basal Length & 29.69 & 30.62 & 29.5 & 28.1 & 28.1 \\
\hline BSL & Basilar Length & 27.71 & 27.61 & 26.7 & 25.7 & 26.1 \\
\hline PPL & Post Palatal Length & 11.93 & 12.52 & 11.8 & 11.4 & 11.25 \\
\hline PAL & Palatilar Length & 15.46 & 14.89 & 14.6 & 13.25 & 13.6 \\
\hline PL & Palatal Length & 17.68 & 17.53 & 17.15 & 15.4 & 15.7 \\
\hline LBP & Length of Bony Plate & 6.42 & 6.51 & 6.4 & 4.9 & 5.9 \\
\hline LIF & Incisive Foramen Length & 7.16 & 6.6 & 5.95 & 6.1 & 5.7 \\
\hline UM1B & Breadth of first upper molar & 2.17 & 2.32 & 2 & 1.7 & 1.8 \\
\hline LR & Length of the Rostrum & 10.74 & 10.91 & 10.7 & 9.3 & 9.9 \\
\hline BR1 & $\begin{array}{l}\text { Breadth of the Rostrum at the } \\
\text { Narrowest point }\end{array}$ & 4.12 & 3.9 & 3.85 & 3.7 & 3.9 \\
\hline LIOB & Least Interorbital Breadth & 4.26 & 4.53 & 4.5 & 3.75 & 4.3 \\
\hline $\mathrm{BB}$ & Breadth of Brain case & 13.4 & 13.4 & 14 & 12.6 & 12.95 \\
\hline MB & Mastoid Breadth & 13.24 & 13.5 & 13.75 & 12.1 & 12.5 \\
\hline $\mathrm{ZB}$ & Zygomatic Breadth & 16.5 & 17.1 & 17.65 & 16 & 16.15 \\
\hline HB & Height of Braincase & 9.74 & 10.24 & 10 & 10.2 & 9.9 \\
\hline $\mathrm{BZP}$ & Breadth of Zygomatic Plate & 5.28 & 4.85 & 5.15 & 4.7 & 5 \\
\hline UDL & Upper Diastema Length & 9 & 9.11 & 7.35 & 7.6 & 7.5 \\
\hline MxTL & Length of Maxillary tooth row & 7.08 & 7.04 & 6.3 & 6.3 & 6.25 \\
\hline LIL1 & $\begin{array}{l}\text { Length of lower incisor/ } \\
\text { Mandibular incisor }\end{array}$ & 7.26 & 8.65 & 7 & 3.3 & 4.7 \\
\hline DD & Depth of Dentary & 11.44 & 11.86 & 11.8 & 10.9 & 10.8 \\
\hline ML & $\begin{array}{l}\text { Greatest Length of Mandible, } \\
\text { excluding Incisors/ Mandible } \\
\text { Length }\end{array}$ & 18.19 & 17.78 & 18.2 & 16.1 & 16.6 \\
\hline LDL & $\begin{array}{l}\text { Lower Diastema/ Mandibular } \\
\text { Diastema Length }\end{array}$ & 4.41 & 3.96 & 3.6 & 2.3 & 3 \\
\hline MnTL & Length of Mandibular Teeth row & 7.02 & 6.87 & 5.95 & 6.1 & 6 \\
\hline
\end{tabular}




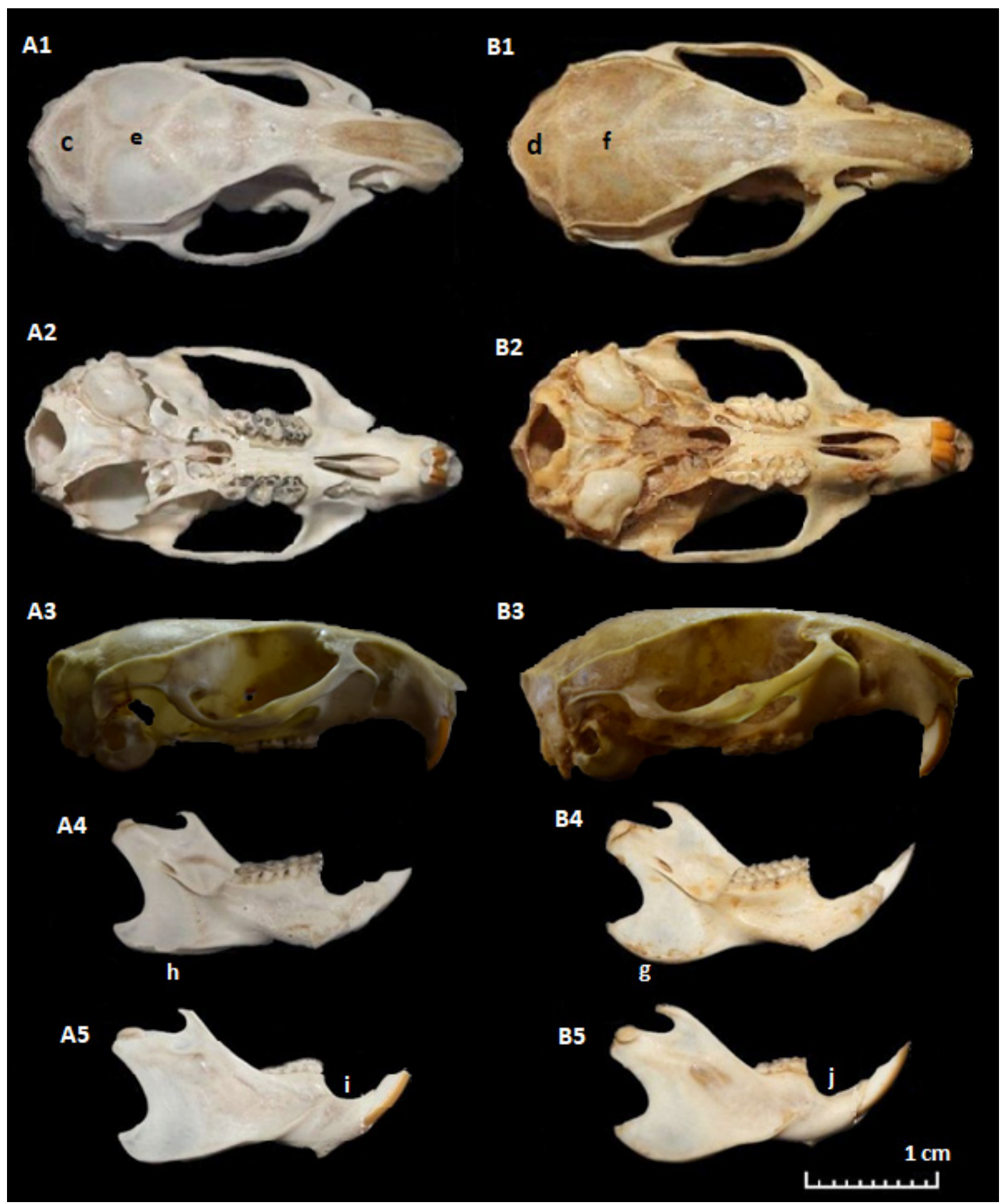

Figure 3: Craniums and mandibule of Golunda ellioti ellioti (PDZ 7) (A) and G. e. nuwara (WHT M 141) (B). 1: Dorsal view of cranium, 2: Ventral view of cranium, 3: Lateral view of cranium, 4: Lateral view of mandible on lingual surface, 5: Lateral view of mandible on labial surface.

Maximum Likelihood (ML) trees of cytochrome- $b$ gene (Figure 4), 16S rRNA and combine genes of cytochrome- $b$ and 16S had the same topology with G. e. ellioti and $G$. $e$. nuwara being reciprocally monophyletic falling as sister taxa. Uncorrected percentage pairwise distance for cytochrome- $b$ gene between the two subspecies is $1.2 \%$ and that for $16 \mathrm{~S}$ gene is $1.1 \%$. There were no Rag 1 sequence differences between the two subspecies. Surprisingly, cytochrome- $b$ divergence between an Indian specimen of Golunda ellioti had a distance of $2.5 \%$ with the widespread
G. e. ellioti from Sri Lanka and 1.8\% distance with G. e. nuwara. 


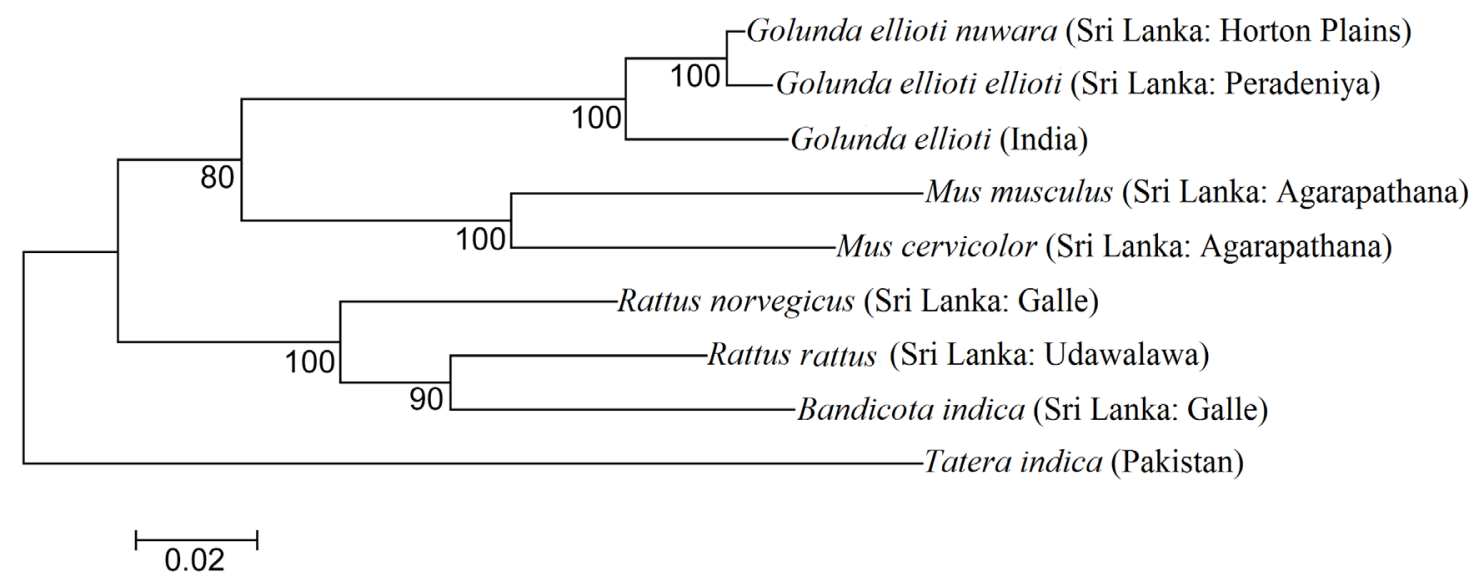

Figure 4: Maximum likelihood tree of cytochrome-b gene to show the placement of Golunda ellioti elioti and G. e. nuwara. Bootstrap values are presented below branches.

\section{DISCUSSION}

Here, we looked at skull measurements, skull characters and molecular data of two subspecies, Golunda e. nuwara and G. e. ellioti. We identified additional differences between the two subspecies; Golunda e. nuwara has larger skull parameters than G. e. ellioti. Interparietal bone of $G$. e. ellioti is rounded in shape whereas that of G. e. nuwara is elongated. Braincase of G. e. ellioti is comparatively more rounded than that of G. e. nuwara. The base of the lower jaw posterior to the angular process is rather flat in $G$. e. ellioti while that of G. e. nuwara is somewhat elongated and curved. Golunda e. ellioti also has a smaller diastema than G. e. nuwara (Figure 3; Table 4).

Though morphologically they can be distinguished from each other, genetic differences remain limited between the subspecies, with a percentage pairwise distance value of $1.2 \%$ for cytochrome- $b$. Mayers et al. (1995) and Steppan (2004) confirm that genetic distances for cytochrome- $b$ gene between subspecies of rodents are in a range that varied by less than $4 \%$. Bradley and Baker (2001) indicated that genetic distance values more than $2 \%$ for cytochrome- $b$ gene are indicative of specific variation. Also, they reported that average distance values within subspecific taxa for cytochrome- $b$ gene are between 0.09 $2.34 \%$ with an average of $1.04 \%$ for rodents.

The two subspecies of G. ellioti in Sri Lanka were recovered as sister taxa in the phylogeny with an Indian G. ellioti falling outside this clade. They were reciprocally monophyletic. Though we do not have a specimen from India for morphological comparison, the available cytochrome- $b$ sequence shows that the genetic divergence of the lowland G. ellioti ellioti and the Indian specimen is slightly larger $(2.5 \%)$ than the genetic distance between G. e. nuwara and Indian specimen (1.8\%), indicating lower rate of divergence in the highland subspecies. Island populations can diverge faster due to smaller population sizes than continental populations (Aleixandre et al., 2013). Similarly, the genetic divergence of the two subspecies may possibly be a result of the population of $G$. e. ellioti being smaller than that of G. e. nuwara. According to the recorded distribution G. e. nuwara, it is plentiful above the 4000 feet while G. e. ellioti is moderately plentiful throughout the Southwestern lowland wet zone and the mid country hills of the Central and Uva provinces to approximately 3000 feet. This subspecies is reported from dry zone in the Southern Province and Kanthlai in North Central province, but not as plentiful as in the wet zone (Phillips, 1980). Hence, its population may be small compared to G. e. nuwara. Absence of G. e. ellioti in the Northern or North Western regions of the country also indicates that the Sri Lankan population may have been isolated even during the times that terrestrial connections existed in the past such as during successive glacial sea-level lowstands. This may have allowed the lowland population to diverge independently.

\section{ACKNOWLEDGEMENT}

We thank National Science Foundation of Sri Lanka for providing funding for this study; Mohomed Bahir, then at Wildlife Heritage Trust (WHT) of Sri Lanka, for providing tissue samples and specimens of Golunda ellioti nuwara from Horton Plains; the Department of Wildlife Conservation, Sri Lanka, for granting permits to collect specimens; and Umesha Dissanayaka, Ama Pothuhera and Lahiru Nanayakkara for field assistance in Peradeniya.

\section{REFERENCES}

Agrawal, V.C. and Chakraborty, S. (1982). Intraspecific geographic variations in the Indian Bush rat, Golunda ellioti J.E. Gray (Rodentia: Muridae). Records of Zoological survey of India 79: 521-530.

Aleixandre, P., Montoya, J.H. and Mila, B. (2013). Speciation on oceanic islands: Rapid adaptive divergence vs. cryptic speciation in a Guadalupe Island songbird (Aves: Junco). PLoS One 8(5): e63242.

Bradley, R.D. and Baker, R.J. (2001). A test of the genetic species concept: cytochrome- $b$ sequences and mammals. Journal of Mammalogy 82(4): 960-973.

Butler, P.M. and Greenwood, M. (1979). Soricidae (Mammalia) from the Early Pleistocene of Olduvai 
Gorge, Tanzania. Zoological Journal of the Linnean Society 67(4): 329-379.

Chevret, P. and Dobigny, G. (2005). Systematics and evolution of the subfamily Gerbillinae (Mammalia, Rodentia, Muridae). Molecular Phylogenetics and Evolution 35(3): 674-688.

Ducroz, J.F., Volobouev, V. and Granjon, L. (2001). An assessment of the systematics of arvicanthine rodents using mitochondrial DNA sequences: evolutionary and biogeographical implications. Journal of mammalian Evolution 8(3): 173-206.

Ellerman, J.R. (1941). The families and genera of living rodents. Vol II-Muridae. London, British Museum of Natural History.

Ellerman, J.R. (1947). A key to the Rodentia inhabiting India, Burma and Ceylon, based on collections in the British Museum. Part II. Journal Mammal 28: 357-387.

Ellerman, J.R. (1963). The Fauna 01 India, Mammalia, 3. Rodentia. Part II. Delhi (Govt. of India).

Kelaart, E.F. (1850). Description of new species and varieties of mammals found in Ceylon. Journal of the Ceylon Branch of the Royal Asiatic Society 2: 208-215.

Kelaart, E.F. (1852). Golunda Gray. Prodromus Faunae Zeylanicae A facsimile reprint of the 1852 and 1854 texts. 1998 WHT publications (private) Limited, Pp.6668.

Myers, P., Lundrigan, B. and Tucker, P.K. (1995). Molecular phylogenetics of oryzomyine rodents: the genus Oligoryzomys. Molecular phylogenetics and evolution 4(4): 372-382.

Meegaskumbura, S., Meegaskumbura, M., Pethiyagoda, R., Manamendra-Arachchi, K. and Schneider, C.J. (2007). Crocidura hikmiya, a new shrew (Mammalia: Soricomorpha: Soricidae) from Sri Lanka. Zootaxa 1665(1): 19-30.

Michaux, J., Chevret, P. and Renaud, S. (2007).
Morphological diversity of Old World rats and mice (Rodentia, Muridae) mandible in relation with phylogeny and adaptation. Journal of Zoological Systematics and Evolutionary Research 45(3): 263279.

Molur, S., Srinivasulu, C., Srinivasulu, B., Walker, S., Nameer, P.O. and Ravikumar, L. (2005). Status of Nonvolant Small Mammals: Conservation Assessment and Management Plan Workshop Report. Zoo Outreach Organisation, Coimbatore, Pp. 618.

Musser, G.G., Lunde, D.P. and Son, N.T. (2006). Description of a new genus and species of rodent (Murinae, Muridae, Rodentia) from the Tower Karst Region of Northeastern Vietnam. American Museum Novitates 1-41.

Niroshini, D.M.C. and Meegaskumbura, S. (2015). Identification of Sri Lankan Muroid Rodents using Hair Anatomy. Ceylon Journal of Science (Biological Sciences 43(2): 17-30.

Phillimore, A.B. and Owens, I.P. (2006). Are subspecies useful in evolutionary and conservation biology? Proceedings of the Royal Society of London B: Biological Sciences 273(1590): 1049-1053.

Phillips, W.W.A. (1928). The bush rat (Golunda ellioti) and its races in Ceylon. Ceylon Journal of Science (section B) part II: 347-349.

Phillips, W.W.A. (1980). A manual of the mammals of Sri Lanka. Wildlife and Nature Protection Society of Sri Lanka, Colombo. 389+xxxv pp.

Steppan, S.J., Adkins, R.M. and Anderson, J. (2004). Phylogeny and Divergence-Date Estimates of Rapid Radiations in Muroid Rodents Based on Multiple Nuclear Genes. Systematic Biology 53(4): 533-553.

Thomas, O. (1923). Scientific Results from the Mammal Survey. No. XLII. The Distribution and Geographical Races of the Golundi Bush Rats (Golunda ellioti). Journal of Bombay Natural History Society 29: 373376.

Wilson, E.O. and Brown, W.L. (1953). The subspecies concept and its taxonomic application. Systematic Zoology 2(3): 97-111. 